\title{
XYLANASE AND CELLULASE ACTIVITIES DURING ANAEROBIC DECOMPOSITION OF THREE AQUATIC MACROPHYTES
}

\author{
Maíra F. Nunes ${ }^{1}$; Marcela B. da Cunha-Santino² ${ }^{2}$ Irineu Bianchini Jr. ${ }^{1,2}$ \\ ${ }^{1}$ Universidade Federal de São Carlos, Programa de Pós-Graduação em Ecologia e Recursos Naturais, São Carlos, SP, Brasil; \\ ${ }^{2}$ Universidade Federal de São Carlos, Departamento de Hidrobiologia, São Carlos, SP, Brasil.
}

Submitted: March 01, 2010; Returned to authors for corrections: March 30, 2010; Approved: June 21, 2010.

\begin{abstract}
Enzymatic activity during decomposition is extremely important to hydrolyze molecules that are assimilated by microorganisms. During aquatic macrophytes decomposition, enzymes act mainly in the breakdown of lignocellulolytic matrix fibers (i.e. cellulose, hemicellulose and lignin) that encompass the refractory fraction from organic matter. Considering the importance of enzymatic activities role in decomposition processes, this study aimed to describe the temporal changes of xylanase and cellulose activities during anaerobic decomposition of Ricciocarpus natans (freely-floating), Oxycaryum cubense (emergent) and Cabomba furcata (submersed). The aquatic macrophytes were collected in Óleo Lagoon, Luiz Antonio, São Paulo, Brazil and bioassays were accomplished. Decomposition chambers from each species $(n=10)$ were set up with dried macrophyte fragments and filtered Óleo Lagoon water. The chambers were incubated at $22.5^{\circ} \mathrm{C}$, in the dark and under anaerobic conditions. Enzymatic activities and remaining organic matter were measured periodically during 90 days. The temporal variation of enzymes showed that $C$. furcata presented the highest decay and the highest maximum enzyme production. Xylanase production was higher than cellulase production for the decomposition of the three aquatic macrophytes species.
\end{abstract}

Key words: anaerobic decomposition, aquatic macrophytes, xylanase, cellulase.

\section{INTRODUCTION}

Decomposition processes are mediated by microorganisms that are extremely important for environment maintenance because of their fundamental role on nutrients and organic matter cycling, changing organic matter into inorganic matter and providing nutrients which propitiates energetic balance in aquatic ecosystems $(27,44)$.

Considered as an important detrital and nutrient source in aquatic environments, the aquatic macrophytes are present mostly in the littoral zones of lakes $(7,37)$. Aquatic macrophytes tissues are constituted by fibers (mainly as particulate organic matter - POM), and by dissolved organic matter (DOM) and dissolved inorganic matter (DIM). Organic matter in these systems is basically composed by non-living matter and detritus that can be found as DOM and POM (21, 23). Decomposition of POM into DOM is mostly mediated by microbial extracellular enzymes (8).

The sediments detritus are basically constituted by fibers (e.g. lignocellulosic matrix) (6). The major component of

*Corresponding Author. Mailing address: Universidade Federal de São Carlos, Programa de Pós-Graduação em Ecologia e Recursos Naturais, São Carlos, SP, Brasil.; E-mail: mairafnunes@ hotmail.com 
lignocellulose materials is cellulose, along with lignin and hemicellulose. The portion known as holocellulose is a combination of cellulose and hemicellulose portions (38). The composition and percentages of these polymers vary for each plant species and can change depending of the growth stage (18). A great variety of fungi and bacteria can fragment these macromolecules using several hydrolytic or oxidative enzymes (30). These compounds are hydrolyzed by cellulases and xylanases from microbial extracellular enzymes (43). Some biotic factors can hinder this process, as microbiota metabolic activity, biomass and diversity (11).

Considering that microbial degradation is the main process during decomposition once it results in a significant mass loss (22) and that enzymes assays can be used to examine microbial activities (28), this study aimed to describe production and temporal activities of xylanase and cellulase during anaerobic decomposition of three aquatic macrophytes: Ricciocarpus natans, Oxycaryum cubense and Cabomba furcata from an oxbow lagoon.

\section{MATERIAL AND METHODS}

\section{Description of sampling site and studied species}

Óleo Lagoon $\left(21^{\circ} 36^{\prime} \mathrm{S}\right.$ and $\left.47^{\circ} 49^{\prime} \mathrm{W}\right)$ is situated within Jataí Ecological Station, Luiz Antonio, São Paulo, Brazil), is one of the many oxbow lagoons comprised in the Mogi-Guaçu river floodplain (39). It is shallow (average $Z=2.55 \mathrm{~m}$ ), small $\left(0.0195 \mathrm{~km}^{2}\right)$, presents low concentrations of dissolved oxygen $\left(4.8 \pm 1.4 \mathrm{mg} \mathrm{L}^{-1}\right)$ and $\mathrm{pH}=5.49 \pm 0.65$ (31). Its littoral zone is colonized by several species of aquatic macrophytes (31). The species selected for this study present different life forms. Ricciocarpus natans (L.) Corda (Ricciaceae family) is a small floating moss (bryophyte) with maximum length of $1.5 \mathrm{~cm}$ (33). Oxycaryum cubense Poepp \& Kunth (Cyperaceae family) is an emergent plant found mainly in the littoral zone of lentic systems, the stolons are scaly, rooting at nodes or with longhanging roots and stems are slender, triangular and erect (20, 16). Cabomba furcata Schult. \& Schult. F. (Cabombaceae family) is a submerged plant rooted to the ground (40).

\section{Water and plant material sampling}

Water samples (20 L) were collected on May, 2009 from littoral and pelagic zone with a $5.0 \mathrm{~L}$ Van Dorn bottle at different depths (surface and bottom). Water samples were mixed in a polyethylene container in order to get vertically integrated samples. In laboratory the samples were pre-filtered through a cellulose ester membrane $(\phi$ pore $=0.45 \mu \mathrm{m}$, Millipore). Entire fresh living mature samples were manually collected on April, 2009 in the littoral zone of the lagoon. In the laboratory, the plants were washed with tap water to remove periphyton, sediment particles and coarse material (29). After washing, each plant material was oven-dried $\left(50^{\circ} \mathrm{C}\right)$, grounded and homogenized. The initial holocellulose content from intact fragments of each species was measured by gravimetric method according to Han and Rowell (15).

\section{Incubations assays}

For each plant species there were prepared 30 chambers containing $500 \mathrm{mg}$ of plant (dry weight) plus $50 \mathrm{~mL}$ of filtered water from the lagoon (in the proportion of $10 \mathrm{~g} \mathrm{~L}^{-1}$ ) the incubations were kept under controlled temperature $\left(22.5^{\circ} \mathrm{C}\right.$; the average temperature of lagoon in 2008), anaerobic condition and in the dark. Prior to the enzyme assays, on each sampling day $(1,3,5,10,15,20,30,45,60$ and 90 days),three chambers of each species were filtered $(\varnothing$. pore $=1.2 \mu \mathrm{m}$; Millipore AP20) in order to fractionate plants and water into POM and DOM. The fractionated POM was dried at $40-50^{\circ} \mathrm{C}$ until constant dry weight and incinerated in a muffle furnace at $550^{\circ} \mathrm{C}$ for two hours, in order to quantify the remaining organic matter content (45).

\section{Mathematical modeling of organic matter decay}

The temporal variations of remaining POM (as ash free) were fitted two a biphasic decay model $(25,19)$ using nonlinear regression, the iterative algorithm of LevenbergMarquardt (34) according to Equation 1:

$$
P O M=\left(P O M_{L S} \times \mathrm{e}^{-\mathrm{k}_{\mathrm{T}} \mathrm{t}}\right)+\left(P O M_{R} \times \mathrm{e}^{-\mathrm{k}_{\mathrm{R}} \mathrm{t}}\right)_{(1),}
$$


where: $\mathrm{POM}_{\mathrm{LS}}=$ initial labile organic matter content $(\%)$; $\mathrm{POM}_{\mathrm{R}}=$ initial particulate refractory organic matter content $(\%) ; \mathrm{k}_{\mathrm{T}}=\mathrm{k}_{1}+\mathrm{k}_{2} ;$ global mass loss coefficient (= labile mineralization coefficient $\left(\mathrm{k}_{1}\right)+$ soluble leachate coefficient $\left(\mathrm{k}_{2}\right)\left(\right.$ day $\left.\left.^{-1}\right)\right) ; \mathrm{k}_{\mathrm{R}}=$ refractory mass loss coefficient $\left(\right.$ day $\left.^{-1}\right)$.

The half-time $\left(t_{1 / 2}\right)$ of organic matter decay was calculated with Equation 2:

$$
\mathrm{t}_{1 / 2}=\ln (0.5) /-\mathrm{k}
$$

where: $\mathrm{k}=$ decay coefficient of each fraction type of the plant; for $\mathrm{POM}_{\mathrm{LS}}$, coefficient used was $\mathrm{k}_{\mathrm{T}}$; and for $\mathrm{POM}_{\mathrm{R}}$, the coefficient used was $k_{R}$.

\section{Enzyme Assays}

From each analyzed chamber (three per plant in each sampling day), two enzyme extracts were prepared with $10 \mathrm{~mL}$ of DOM and $0.3 \mathrm{~g}$ POM (fresh mass). In sequence, samples were homogenized with an Ultra-Turrax (model T10; Germany), sonicated with an ultrasound (Unique, Brazil) and centrifuged $\left(3,000 \times \mathrm{g}, 30 \mathrm{~min}, 4^{\circ} \mathrm{C}\right.$; Heraeus Instruments, Megafuge 3.0R, Germany) for determination of cellulase and xylanase activities separately. The assays were performed in duplicate for each enzyme. Both cellulase $(\mathrm{C} 1=$ endoglucanase - EC: 3.2.1.4 and exoglucanase - EC: 3.2.1.91) and xylanase (ß-xylanase - EC 3.2.1.8) activities were determined spectrophotometrically (Amersham Biosciences, Ultrospec 2100 pro, Sweden) by measuring the concentration of released reducing sugar acting on specific substrates (41): solution of xylan (modified from Ghose and Bisaria) (12) and pure cellulose filter (Whatman $\left.n^{\circ} 1\right)(26)$. One unit of cellulase or xylanase activity was referred as the amount of enzyme that liberates $1 \mu \mathrm{mol}$ of reducing sugar under the assay condition. Cellulase activities were expressed as mol of reducing sugar per $\mathrm{g}$ of fresh weight from $C$. furcata, $O$. cubense and $R$. natans decomposition and calculated as activity day ${ }^{-1}$

Cumulative cellulase and xylanase activities were calculated by integrating the enzyme activities over time.

\section{Mathematical modeling of cumulative enzyme production}

\section{through time}

The temporal variations of cumulative cellulase and xylanase activities were fitted to a sigmoidal curve using nonlinear regression (iterative algorithm of Levenberg-Marquardt) following Press et al. (34). The coefficient of enzymatic activity $\left(\mathrm{k}_{\mathrm{p}}\right)$ values were derived from the sigmoidal fittings. In these procedures, the time evolution of enzymes production was described by Equation 3:

$$
E=E_{\max }\left(1-e^{-k_{p} t}\right)_{(3)}
$$

where: $\mathrm{E}=$ accumulated produced enzyme $\left(\mu \operatorname{molmin}^{-1} \mathrm{ml}^{-1} \mathrm{~g}^{-1}\right)$; $\mathrm{E}_{\max }=$ maximum enzyme produced $\left(\mu \operatorname{molmin}{ }^{-1} \mathrm{ml}^{-1} \mathrm{~g}^{-1}\right) ; \mathrm{k}_{\mathrm{P}}=$ enzyme production coefficient $\left(\right.$ day $\left.^{-1}\right) ; \mathrm{t}=$ time (day).

The doubling-time $\left(\mathrm{D}_{1 / 2}\right)$ of maximum enzyme production was calculated according to Equation 2; in this case the coefficient used was $\mathrm{k}_{\mathrm{P}}$.

\section{Statistical analysis}

The non-parametric test Kruskal Wallis was applied to corroborate data similarities and differences between the species, with a significant $\alpha=0.05$.

\section{RESULTS}

\section{POM decay}

The temporal organic matter decay presented a biphasic pattern for the three species (Figure 1). This pattern occurred because of the faster mass losses in the beginning of the experiment, representing $\mathrm{POM}_{\mathrm{LS}}$ percentages (which varied from $5.2 \%$ for $O$. cubense to $27.8 \%$ for $C$. furcata), and slower decay later, representing $\mathrm{POM}_{\mathrm{R}}$ percentages (which varied from $70 \%$ for C. furcata to $94.8 \%$ for O. cubense).

The determination coefficients $\left(\mathrm{r}^{2}\right)$ from decay fittings varied from 0.86 ( $R$. natans) to 0.99 (O. cubense). The statistical analysis of the kinetics model pointed significantly differences between $C$. furcata and $R$. natans decay $(\mathrm{p}<0.01$ ) 
and $C$. furcata and $O$. cubense $(\mathrm{p}<0.001)$ and similarities between $R$. natans and $O$. cubense ( $\mathrm{p}>0.05)$.

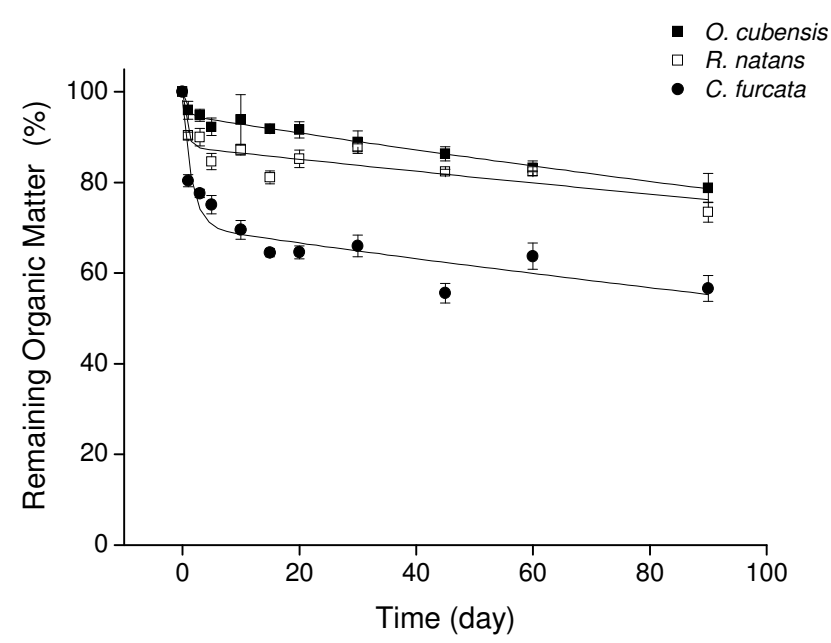

Figure 1. Temporal organic matter decay for the three studied species and mathematical modeling applied.

\section{Cellulase and xylanase activities}

The temporal variations in cellulase and xylanase activities are shown in Figure 2. For the selected species, production of xylanase was higher than cellulase and the greatest difference between both enzymes production occurred in decomposition of $O$. cubense, where production of xylanase was ca. 16 times higher than cellulase production (Table 2). Table 2 also shows that $E_{\max }$ for cellulose varied from $0.107 \pm 0.121 \mathrm{~mol} \mathrm{~min}^{-1} 1 \mathrm{ml}^{-}$ ${ }^{1} \mathrm{~g}^{-1}$ (O. cubense) to $0.995 \pm 0.303 \mathrm{~mol} \mathrm{~min}^{-1} \mathrm{ml}^{-1} \mathrm{~g}^{-1}$ (C. furcata) and for xylanase it varied from $1.677 \pm 0.073 \mathrm{~mol} \mathrm{~min}^{-1} \mathrm{ml}^{-1} \mathrm{~g}^{-1}$ (R. natans) to $11.301 \pm 0.304 \mathrm{~mol} \mathrm{~min}^{-1} \mathrm{ml}^{-1} \mathrm{~g}^{-1}$ (C. furcata).

The temporal patterns for enzymes production during $R$. natans and $O$. cubense decomposition were similar and $C$. furcata decay presented the highest production of both enzymes. For xylanase, difference were 6.8-fold the production measured for $O$. cubense and $R$. natans decomposition and for cellulase, the production difference was 9.3 times over $O$. cubense decomposition and 6.7 times over $R$. natans decomposition.
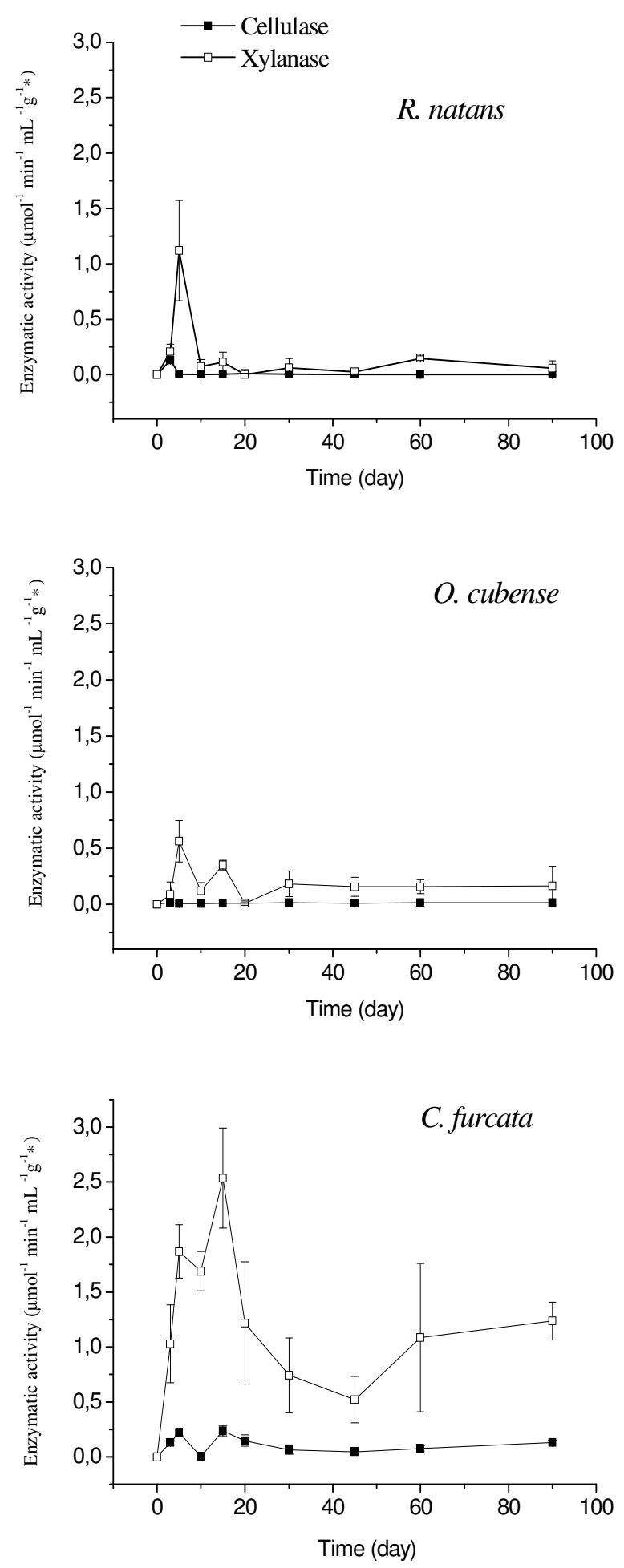

*Fresh mass

Figure 2. Temporal variation and standard deviation of cellulase (ם) and xylanase $(\square)$ production during anaerobic decomposition of $R$. natans, $O$. cubense and $C$. furcata. 
Table 1. Parameters obtained from organic matter decay model, where $\mathrm{POM}_{\mathrm{L}}=$ labile fraction of organic matter; $\mathrm{k}_{\mathrm{T}}=\mathrm{Global}$ decay coefficient (labile fraction mineralization coefficient + leaching coefficient) $\mathrm{POM}_{\mathrm{R}}=$ refractory fraction of organic matter; $\mathrm{k}_{\mathrm{R}}=$ refractory fraction mineralization coefficient; $t^{1} / 2=$ half-time; $E=$ error.

\begin{tabular}{lccccccccccc}
\hline & $\begin{array}{c}\left(\mathbf{P O M}_{\mathbf{L S}}\right) \\
(\%)\end{array}$ & $\mathbf{E}$ & $\begin{array}{c}\mathbf{k}_{\mathbf{T}}{ }_{-1} \\
\left(\mathbf{d a y}^{-}\right)\end{array}$ & $\mathbf{E}$ & $\begin{array}{c}\mathbf{t}_{1 / 2} \\
(\mathbf{d a y})\end{array}$ & $\begin{array}{c}\left(\mathbf{P O M}_{\mathbf{R}}\right) \\
(\boldsymbol{\%})\end{array}$ & $\mathbf{E}$ & $\begin{array}{c}\mathbf{k}_{\mathbf{R}}{ }^{-1} \\
\left(\mathbf{d a y}^{-1}\right)\end{array}$ & $\mathbf{E}$ & $\begin{array}{c}\mathbf{t}_{1 / 2} \\
(\mathbf{d a y})\end{array}$ & $\mathbf{r}^{\mathbf{2}}$ \\
\hline O. cubense & 5.2 & 0.9 & 1.31 & 0.64 & 0.53 & 94.8 & 0.4 & 0.0021 & 0.0001 & 330 & 0.99 \\
C. furcata & 27.8 & 4.9 & 0.61 & 0.28 & 1.14 & 70 & 2.9 & 0.0027 & 0.0010 & 259 & 0.92 \\
R. natans & 12.1 & 3.4 & 1.41 & 1.16 & 0.49 & 87.9 & 1.6 & 0.0016 & 0.0005 & 433 & 0.86 \\
\hline
\end{tabular}

In the beginning of the process (ca. first $20^{\text {th }}$ days) a higher amount of xylanase was produced and cellulase production showed no great variations, presenting low production during experimental period tending to stabilization (Figure 2).

The determination coefficients $\left(\mathrm{r}^{2}\right)$ varied from 0.96 to 0.99 for the kinetic model fitting (Figure 2). According to the statistical analysis, xylanase production was similar between $O$. cubense and $R$. natans decomposition ( $\mathrm{p}>0.05$ ). Yet, $C$. furcata and $R$. natans decomposition presented differences ( $\mathrm{p}<$ 0.01). O. cubense presented a significant difference with $C$. furcata $(\mathrm{p}<0.001)$. For cellulase production during decomposition, it was pointed differences between $C$. furcata and $R$. natans $(\mathrm{p}<0.01)$ and $O$. cubense $(\mathrm{p}<0.05)$, and similarities with $O$. cubense and $R$. natans $(\mathrm{p}>0.05)$.

\section{Holocellulose content}

Initial holocellulose contents for the three studied species were: $79.55 \pm 6.63 \%$ (R. natans); $72.77 \pm 10.53 \%$ (O. cubense); $65.99 \pm 3.79 \%$ (C. furcata).

\section{DISCUSSION}

The analysis and comparison between results of both enzyme production and POM decay shows that there is a relation between these two parameters. The decomposition of C. furcata, which presented the highest enzyme production, showed the highest organic matter loose of mass before the $10^{\text {th }}$ day of experiment (Figure 1). Decomposition of $R$. natans and
O. cubense had similarities in both enzymatic production (xylanase and cellulase) and POM decay. The high determination coefficient from kinetic fittings indicates that this model was adequate to represent two phase organic matter decay during anaerobic decomposition and also enzyme production.

According to the degrading potential of detritus, the POM can be differed in labile and refractory fractions (2, 10, 42). High mass decay observed in the beginning of decomposition occurred because debris usually loses their labile fraction (more reactive and easily processed by microorganisms) by leaching process. Labile fraction is characterized by a faster decay, while refractory decay can be 10 to 20 times slower (14).

C. furcata presented the highest percentage of labile organic matter (Figure 1), indicating that its debris decomposed faster than the other studied species. Another result which supports this fact is that for the refractory portion, $C$. furcata also showed the shortest half-time period (Table 1), which means that it demands a shorter period to be completely decomposed.

Bioassays carried out with $O$. cubense presented a higher cellulose percentage than $C$. furcata (9), configuring that $C$. furcata is, among the three studied species, the more susceptible to decomposition. Submerged plants, such as $C$. furcata presents less structural materials contents in their cell wall than the emergent macrophytes (3). 
Table 2. Parameters obtained from kinetic model for accumulated enzyme production, where: $\mathrm{E}_{\max }=$ maximum enzyme production, $\mathrm{E}=$ error, $\mathrm{k}_{\mathrm{P}}=$ enzyme production coefficient and $\mathrm{D}_{1 / 2}=$ doubling-time.

\begin{tabular}{|c|c|c|c|c|c|c|}
\hline & $\begin{array}{c}\mathbf{E}_{\max } \\
\left(\mathrm{mol} \mathrm{min}^{-1} \mathrm{ml}^{-1} \mathrm{~g}^{-1}\right)\end{array}$ & $\mathbf{E}$ & $\begin{array}{c}\mathbf{k}_{\mathbf{P}} \\
\left(\mathrm{day}^{-1}\right)\end{array}$ & $\mathbf{E}$ & $\begin{array}{c}D_{1 / 2} \\
\text { (days) }\end{array}$ & $\mathbf{r}^{2}$ \\
\hline \multicolumn{7}{|c|}{ Celullase } \\
\hline$R$. natans & 0.148 & 0.059 & 0.632 & 2.362 & 1.10 & 0.96 \\
\hline C. furcata & 0.995 & 0.303 & 0.058 & 0.049 & 12.02 & 0.99 \\
\hline O. cubense & 0.107 & 0.121 & 0.030 & 0.073 & 22.78 & 0.98 \\
\hline \multicolumn{7}{|c|}{ Xylanase } \\
\hline$R$. natans & 1.677 & 0.073 & 0.165 & 0.031 & 4.21 & 0.96 \\
\hline C. furcata & 11.301 & 0.304 & 0.057 & 0.004 & 12.06 & 0.99 \\
\hline O. cubense & 1.679 & 0.064 & 0.061 & 0.007 & 11.41 & 0.98 \\
\hline
\end{tabular}

A compilation about degradable fractions of macrophyte species showed that POM content calculated for $R$. natans presented a smaller percentage of the labile/soluble (12.1\%) fraction than the average values for floating species $(54.4 \%)$; for $C$. furcata, the percentage of labile/soluble fraction $(27.8 \%)$ was close to the average found for submerged species $(34.1 \%)$; for $O$. cubense $(5.2 \%)$ this percentage was smaller than parameterized for emergent species (31.6\%) (5), showing that cell wall constitution vary even between similar types of plants.

Holocellulose content data showed no directly proportionality with enzyme activity, this result is probably explained by physical and chemical characteristics of substrates (e.g. lignin/hemicellulose association and degree of cellulose cristallinity) that contribute with cellulose recalcitrance to enzyme hydrolysis. As cellulose chains are tightly packed with hemicellulose and lignin, it has been proposed that, to an efficient hydrolysis, cellulase must delaminate and disrupt the surface area to create a larger accessibility to the enzymes by increasing the reactive internal surface (1).

Xylanase production was higher than cellulase production probably because structures of hemicelluloses are easily hydrolysable polymers than cellulose (30). Gilbert \& Hazelwood (13) reported that although the higher complexity of xylan in comparison with cellulose and the needs of several types of enzymes to hydrolyze this compound, this polymer do not form tightly packed structures what results in an easier accessibility to hydrolytic enzymes. Consequently, the specific activity of xylanase is ca. 2 to 3 times higher than for cellulase hydrolysis of crystalline cellulose, showing that the action of each enzyme and the fiber structure may also have caused these differences.

About 5-10\% of cellulose is degraded in nature under anaerobic condition. The cellulose system of anaerobic microorganisms is clearly different from that of aerobic fungi and bacteria (30). The action of each enzyme and the fiber structure may also have caused these differences.

As hemicelluloses surround the cellulose microfibrils it must be degraded, at least in part, before cellulose in plant cell walls (24). Xylans are the principal class of hemicelluloses in angiosperms contributing with ca. 15 to $30 \%$ of the total dry weight (32).

Decomposition experiments with $O$. cubense, C. furcata and Ludwigia inclinata under aerobic and anaerobic conditions, showed that $C$. furcata was the only species which presented a higher xylanase activity under anaerobic conditions, the same occurred in present study. The other species presented higher xylanase activity under aerobic conditions (36).

Ghose and Bisharia (12) suggested that xylanase helps to create more accessible cellulosic regions, thereby resulting in a higher sugar production by cellulase. Most cellulose is degraded aerobically, only $5-10 \%$ is degraded anaerobically (24).

In terms of structure and appearance, cellulose appears in nature associated with other plant substances, embedded in a matrix primarily containing hemicelluloses, pectin, and proteins. This association may affect its biodegradation. High 
compression strengths are achieved when lignin (a complex aromatic polymer) replaces water in the matrix of cell walls. Lignification greatly increases bonding within the wall and produces rigid, woody tissues $(24,30)$. Only a small percentage of non-organized cellulose chain form amorphous cellulose which conformation turns it more susceptible to enzymatic degradation (4).

The ecology of cellulose degradation in anaerobic environments is very complex; it involves numerous, varied interactions of metabolically diverse microorganisms whose activities are influenced by a wide range of environmental factors (24). Some microorganisms simultaneously excreted both cellulase and xylanase and/or that a certain amount of enzymes had both cellulolytic and xylanolytic abilities (43).

Cunha-Santino and Bianchini Jr. (11) measured cellulolytic activities from $U$. breviscapa detritus and found a higher activity of integral detritus at $15^{\circ} \mathrm{C}$, showing that temperature affects cellulase activity.

A study from Romaní et al. (35) suggested that some interactions between fungi and bacteria communities may impact their own activities, influencing decomposition processes by altering the growth, enzyme production of microorganisms and quality of released DOM and intermediate decomposition products. In present assay, besides the interference of physical conditions (temperature and dissolved oxygen availability), some biotic factors could have interfered enzymatic activities.

Following a proposed four stage model for decomposition processes (43), the present study contemplated the second phase $\left(1^{\text {st }}\right.$ month), characterized by a rapid increase in biomass of decomposing bacteria followed by xylanase and cellulase activities, and the third phase (between $2^{\text {nd }}$ and $5^{\text {th }}$ months), characterized by low enzyme activities, low decay rates and constant decomposer bacteria biomass.

Overall, the results allow us to infer that for Óleo Lagoon, after senescence, the macrophytes detritus lost great amounts of DOM and POM, the dissolved detritus is processes within water column and POM (the refractory fraction) tends to accumulate in the upper layers of sediment that usually presents a lower oxi-reduction potential allowing anaerobic metabolism to predominate. In the first stage of decomposition this conditions stimulated the xylanase production over cellulase during breakdown of lignocellulosic detritus. The accumulation over time of POM from autochthonous source as macrophyte detritus turns sediment of Óleo Lagoon a suitable site to degradation of these natural polymers regarding to oxireduction potential.

\section{ACKNOWLEDGMENTS}

Authors thank to Conselho Nacional de Desenvolvimento Científico e Tecnológico (CNPq), processes 135763/2008-8 and 300959/2004-4, and Fundação de Amparo à Pesquisa do Estado de São Paulo (FAPESP), process 2007/02683-7, for scholarship concession and financial support to this work.

\section{REFERENCES}

1. Arantes, V.; Saddler, J. (2010). Access to cellulose limits the efficiency of enzymatic hydrolysis: the role of amorphogenesis. Biotechnol for Biofuels. http://www.biotechnologyforbiofuels.com/content/3/1/4.

2. Asaeda,T.; Trung, V.K.; Manatunge, J. (2000). Modeling the effects of macrophyte growth decomposition on the nutrient budget in shallow lakes. Aquat Bot. 68, 217-237.

3. Barbieri, R. (1984). Estudo da composição química de algumas espécies de macrófitas aquáticas e suas implicações para o metabolismo da represa do Lobo (BROA). São Carlos, Brazil, 221 p. (M. Sc. dissertation Programa de Pós-graduação em Ecologia e Recursos Naturais. UFSCar).

4. Béguin, P.; Aubert, J.P. (1994). The biological degradation of cellulose. FEMS Microbiol Rev. 13, 25-58.

5. Bianchini Jr., I. (2003). Modelos de crescimento e decomposição de macrófitas aquáticas. In: Thomaz, S.M.; Bini, L.B. (eds). Ecologia $e$ manejo de macrófitas aquáticas. EDUEM, Maringá, Brazil, p. 85-126.

6. Bianchini Jr., I.; Cunha-Santino, M.B.; Peret, A.M. (2008). Oxygen demand during mineralization of aquatic macrophytes from an oxbow lake. Braz. J. Biol.68(1), 61-67.

7. Carpenter, S.R. (1980). Enrichment of lake Wingra, Winsconsin, by submerged organic matter decay. Ecology, 61(5).

8. Chróst, R.J. (1991). Environmental Control of the synthesis and activity of aquatic microbial ectoenzymes. In: Chróst, R.J. (ed.) Microbial Enzymes in Aquatic Environments, Springer-Verlag, New York, USA, 29-60.

9. Cunha, M.B.; Bianchini Jr., I. (1998). Cinéticas de mineralização aeróbia 
de celulose e lignina durante a degradação aeróbia de Cabomba piauhyensis e Scirpus cubensis. Acta Limnol. Bras. 10 (2), 59-69.

10. Cunha-Santino, M.B; Bianchini, Jr., I.(2000). Consumo de oxigênio durante a mineralização aeróbia e anaeróbia de Salvinia auriculata da lagoa do Infernão. In: Santos, J.E; Pires, J.S.R. (Eds.). Estudos Integrados em Ecossistemas- Estação Ecológica do Jataí. São Carlos: Rima. vol. 2, 631-643.

11. Cunha-Santino, M.B.; Bianchini Jr., I. (2007). Cellulase activities during decomposition of a submerged aquatic macrophyte (Utricularia breviscapa): a microcosm assay. Braz. J. Microbiol.38, 230-236

12. Ghose, T.K.; Bisaria, V.S. (1987). Measurement of hemicellulase activities part 1: xylanases. Pure \& AppI. Chem. 59 (12), 1739-1752.

13. Gilbert, H.J.; Hazelwood, G.P. (1993). Bacterial cellulases and xylanases, J. Gen. Microbiol. 139, 187-194.

14. Guillon, D.; Joffrem R.; Ibrahima, A. (1994). Initial dynamics properties and decay rate: a microcosm experiment in Mediterranean species. Can. J. Bot. 72, 946-954.

15. Han, J.S.; Rowell, J.S. Chemical Composition of Fibers. (1997). In: Rowell, R.M.; Young, R.A.; Rowell, J.K. (Eds). Paper and composites from agro-based resources. Flórida, CRC Press, p.83-134.

16. Hoehne, F. C. (1979). Plantas Aquáticas.São Paulo: Instituto de Botânica.

17. Jackson, C.R.; Foreman, C.M.; Sinsabaugh, R.L. (1995). Microbial enzyme activities as indicators of organic matter processing rates in a Lake Erie coastal wetland. Freshw. Biol. 34, 329-342.

18. Jeffries, T. W. (1994). Biodegradation of lignin and hemicelluloses, In: Ratledge C (Ed.) Biochemistry of microbial degradation. Kluwer, Dordrecht, p. 233-277.

19. Jenkinson, D.S. (1977). Studies on the decomposition of plant material in soil. V: The effect of plant cover and soil type on the loss of carbon from 14C-labelled ryegrass. Europ. J. Soil Sci. 19, 25-39.

20. Joly, A.B. (1977). Botânica: introdução à taxonomia vegetal. São Paulo: Companhia Editora Nacional.

21. Jonsson, A.; Melli, M.; Bergstrosm, A.K.; Janson, M. (2001). Whole-lake mineralization of allochtonous and autochtnous organic carbon in a large humic lake (Ortasket, N. Sweden). Limnol. Oceanogr. 46, 1691-1700.

22. Kok, C.J; Van der Velde, G. (1991). The influence of selected water quality parameters on the decay rate and exoenzymatic activity of detritus of Nymphaeaalba L. floating leaf blades in laboratory experiments. Oecologia (Heidelb.), 88, 311-316.

23. Kritzberg, E.S.; Cole, J.J.; Pace, M.L.; Granéli, W., Bade, D.L. (2004). Autochtonous versus allochtonous carbon sources to bacteria: results from whole lake $13 \mathrm{C}$ addition experiments. Limnol. Oceanogr. 49, 588596

24. Leschine, S.B. (1995). Cellulose degradation in anaerobic environments. Annu. Rev. Microbiol. 49, 399-426.

25. Lousier, J.D.; Parkinson, D. (1976). Litter decomposition in a cool temperate deciduous forest. Can. J. Bot. 54, 419-436.
26. Mandels, M.; Andreotti, R.; Roche, C. (1975). Measurement of saccharifying cellulose. Biotechnol. Bioeng. Symp. 6, 21-33.

27. Moorhead, D.L.; Sinsabaugh, R.L.; Linkins, A. E.; Reynolds, J.F. (1996). Decomposition processes: modelling approaches and applications. Sci. Total Environ. 183, 137-149

28. Moorhead, D.L.; Sinsabaugh, R.L. (2000). Simulated pattern of litter decay predict patterns of extracellular enzyme activities. Appl. Soil Ecol. 14, 71-79.

29. Ogburn III, R.W.; Brezonick, P.L.; Delfino, J.J. (1987). Effect of pH on phosphorous release during macrophyte (Eleocharis $\mathrm{sp}$ ) decomposition. Water Resour. Bul. 23, 829-831.

30. Pérez, J.; Muñoz-Dorado, J.; Rubia, T.; Martinez, J. (2002). Biodegradation and biological treatments of cellulose, hemicellulose and lignin: an overview. Int. Microbiol. 5, 53-63.

31. Petracco, P. (2006). Efeito das variáveis abióticas na produção primária de Egeria najas e Utricularia breviscapa da lagoa do Óleo (Estação Ecológica de Jataí, Luiz Antônio, SP). São Carlos, Brasil, 110p. (Ph.D. Thesis. Programa de Pós-Graduação em Ecologia e Recursos Naturais, UFSCar).

32. Polizeli, M.L.T.M; Rizzati, A.C.S.; Monti, R.; Terenzi, H.F.; Jorge, J.A.; Amorim, D.S. (2005). Xylanases from fungi: properties and industrial applications Appl. Microbiol. Biotechnol. 67, 577-591.

33. Pott, V. J.; Pott, A. (2000). Plantas aquáticas do Pantanal. Brasília: Embrapa.

34. Press, W.H.; Teukolsky, S.A.; Vetterling, W.T.; Flannery, B.P. (1993). Numerical Recipes in $C$ : the art of scientific computing. Cambridge University Press, New York.

35. Romaní, A.M.; Fischer, H.; Mille-Lindblom, C.; Tranvik, L. J. (2006). Interactions of bacteria and fungi on decomposing litter: differential extracellular enzyme activities. Ecology. 87 (10), 2559-2569.

36. Romeiro, F. (2005) Bioensaios de decomposição anaeróbia macrófitas aquáticas da lagoa do Óleo (Estação Ecológica de Jataí, Luiz Antonio $S P$ ). São Carlos, Brasil. (M sc. Dissertation. Programa de Pós Graduação em Ecologia e Recursos Naturais, UFSCar).

37. Rooney, N.; Kalf, J. (2000). Inter-annual variation in submerged macrophyte community biomass and distribution: the influence of temperature and lake morphometry. Aquat. Bot. 68, 321-335.

38. Rowell, R.M.; Han, J.S; Rowell, J.S. (2000) Characterization and Factors Effecting Fiber Properties. In: Frollini, E.; Alcides, L.L.; Mattoso, H.C. (Eds). Natural polymers and agrofibers based composites: preparation, properties and applications. Brasil, EMBRAPA Instrumentação Agropecuária, p. 115-134.

39. Santos, J.E.; Mozeto, A.A. (1992). Programa de análise de ecossistemas e monitoramento ambiental: Estação Ecológica do Jataí (Luiz Antônio, SP). Ecologia de áreas alagáveis da planície do rio Mogi-Guaçu. Projeto Jataí. São Carlos. PPG-ERN/UFSCar

40. Souza, V.C; Lorenzi, H. (2005). Botânica sistemática: guia ilustrado para identificação das famílias de Angiospermas da flora brasileira, 
baseado em APG II. Instituto Plantarum de Estudos da Flora. Nova Odessa, Brazil.

41. Somogyi, M. (1952). Notes on sugar determination. J. Biol. Chem., 195, 19-23.

42. Swift, M.J; Heal, D.W; Anderson, J.M. (1979) Studies in ecology. Decomposition in terrestrial ecosystems. Blackwell. Oxford, England.

43. Tanaka, Y. (1993). Activities and properties of cellulase and xylanase associated with Phragmites leaf litter in a seawater lake. Hydrobiologia. 262, 65-75.

44. Wetzel, R.G. (1995). Death, detritus and energy flow in aquatic ecosystems. Freshwater Biol. 33, 83-89.

45. Wetzel, R.G.; Likens, G.E. (1991) Limnological analysis. SpringVerlag.New York, USA. 